(C) Dereito Vol.29, n01:77-94 (Xaneiro-Xuño, 2020) • ISSN 1132-9947

\title{
FINDING CAUSAL CONNECTION BETWEEN ASBESTOS AND MESOTHELIOMA IN THE UK TORT LAW
}

Encontrando el nexo causal entre el amianto y el mesotelioma en el Derecho de daños del Reino Unido

DOI: $\underline{\text { http://dx.doi.org/10.15304/dereito.29.1.6457 }}$

BOHDAN KARNAUKH ${ }^{1}$

Associate Professor

Yaroslav Mudryi National Law University (Kharkiv, Ukraine)

b.p.karnauh@nlu.edu.ua

\section{Resumen}

La ciencia médica ha probado que las fibras de amianto son cancerígenas y pueden causar mesotelioma. En consecuencia, desde el punto de vista del Derecho de daños, una persona que padezca mesotelioma debería tener derecho a reclamar una compensación de quien le haya expuesto al polvo de amianto. Sin embargo, las cosas no son tan sencillas como pudiera parecer a simple vista. El objetivo de este trabajo es seguir el desarrollo de la jurisprudencia y el Derecho positivo del Reino Unido respecto de la compensación por daños causados por un mesotelioma relacionado con el amianto. La metodología del artículo se basa en un análisis cronológico que refleja la progresiva evolución del enfoque adoptado por la jurisprudencia del Reino Unido, con respecto a la cuestión del nexo causal, en los casos de mesotelioma relacionado con el amianto. Finalmente, el autor muestra cómo el enfoque inicialmente concebido únicamente para el mesotelioma ha afectado a la prueba del nexo causal en otros casos de enfermedad por múltiples agentes.

Palabras clave: Amianto; mesotelioma; daños causados por sustancias tóxicas; nexo causal.

\section{Abstract}

It has been proven by medical science that asbestos fibers are carcinogenic and can cause mesothelioma. Consequently, from the standpoint of tort law a person suffering from mesothelioma should be entitled to claim compensation from the one who exposed this person to asbestos dust. However, things are not as straightforward as it may seem at first glance. The aim of the paper is to track the development of case law and statutory law of the United Kingdom regarding the compensation of damage caused by asbestos-related mesothelioma. The methodology of the paper is based on a chronological survey showing the gradual evolution of the UK case law approach to causation in asbestos-related mesothelioma cases. Eventually the author shows how the approach at

${ }^{1}$ Department of Civil Law No. 1

Recibido: 20/06/2020. Aceptado: 16/07/2020. 
first fashioned for mesothelioma only has affected the proof of causation in other cases including multi-agent disease cases.

Keywords: Asbestos; mesothelioma; toxic tort; causation.

\section{SUMMARY}

1. INTRODUCTION.; 2.- PROOF OF CAUSATION IN TORT LAW: GENERAL RULES., 3.- WHAT IS SO SPECIAL ABOUT THE ASBESTOS-RELATED MESOTHELIOMA CASES?; 4.- FAIRCHILD EXCEPTION: MULTIPLE TORTIOUS CAUSES COMPETING.; 5.- BARKER CASE: MULTIPLE BOTH TORTIOUS AND NON-TORTIOUS CAUSES COMPETING BUT THE LIABILITY IS PROPORTIONAL.; 6.- COMPENSATION ACT 2006 AND SIENKIEWICZ CASE: BACK TO LIABILITY IN SOLIDUM AND "MATERIAL INCREASE IN RISK" EXPLAINED.; 7.- BEYOND MESOTHELIOMA: FAIRCHILD EXCEPTION APPLIED TO MULTI-AGENT DISEASE CASES.; 8.- CONCLUSIONS.; 9.BIBLIOGRAPHY.; 10.- CASES.

\section{INTRODUCTION}

Asbestos is an umbrella term encompassing six natural silicate minerals that have fiber structure, namely chrysotile, crocidolite, amosite, anthophyllite, tremolite and actinolite. Asbestos has low thermal- and electroconductivity, it is fire-resistive, weatherproof and due to its capability of being incorporated into inorganic and organic binders it can be used in production of numerous composites (so far there are more than $3000)^{2}$. Because of its physical properties asbestos is widely used in many branches of industry, first of all for thermal insulation and fireproofing in industrial and residential construction, engineering, and the like. Asbestos is used in production of numerous goods, such as roofing materials (asbestos sheeting), chrysotile cement pipes, fireproof fabrics (for firefighters, metallurgists and electric welders workwear) and many other items.

Asbestos has been commercially used since $1860 s^{3}$. But in 1930 s medical science revealed correlation between inhaling asbestos fibers and a number of dangerous (primarily pulmonary) diseases such as pulmonary and bronchial catarrh, asthma, bronchitis, fibrosis of the lungs, as well as secondary changes such as local and diffuse emphysema ${ }^{4}$. Report on Effects of Asbestos Dust on the Lungs and Dust Suppression in the Asbestos Industry by E. R. A. Merewether and C. W. Price was one of the

\footnotetext{
2 BMZ, "Asbestos". In: Environmental Handbook: documentation on monitoring and evaluating environmental impacts. Vol. III: Compendium of Environmental Standards, Vieweg, Eschborn, 1995, available at http://wgbis.ces.iisc.ernet.in/energy/HC270799/HDL/ENV/enven/vol313.htm.

3 P. D. CARRINGTon, "Asbestos Lessons: The Consequences of Asbestos Litigation", The Review of Litigation, vol. 26, no 3, 2007, p. 585.

${ }^{4}$ E. R. A. Merewether \& C. W. Price, Report on Effects of Asbestos Dust on the Lungs and Dust Suppression in the Asbestos Industry, His Majesty's Stationary Office, London 1930, p. 5.
} 
pathbreaking studies on the issue. In 1935 the correlation between inhaling asbestos fibers and lung cancer was revealed ${ }^{5}$.

Somewhere since 1960s it has been widely known that inhaling the asbestos dust can lead to the development of mesothelioma. It is a malignant tumor that usually occurs in the pleura ( $88.8 \%$ of cases), rarely - in the abdominal cavity $(9.6 \%)$ or pericardium $(0.7 \%)^{6}$ and has a lethal consequence: median survival amounts to 9-12 months ${ }^{7}$. Lord Bingham noticed "[i]n the absence of occupational exposure to asbestos dust it is a very rare tumour indeed, afflicting no more than about one person in a million per year. But the incidence of the tumour among those occupationally exposed to asbestos dust is about 1,000 times greater than in the general population"8.

In 1972 International Agency for Research on Cancer (IARC) in Lyon (France) held a Working Conference further to which the proceedings were published under the title "Biological Effects of Asbestos"9. Thus far pursuant to World Cancer Report 2014 (by IARC) asbestos of all forms is recognized as a group 1 carcinogen ${ }^{10}$. It is acknowledged that asbestos can cause larynx cancer, lung cancer, ovary cancer and mesothelioma ${ }^{11}$.

The above-mentioned results of medical research have naturally provoked the adoption of regulatory acts aimed at minimizing the risks of asbestos use in industry. Thus in 1986 International Labour Organization adopted Convention and Recommendation concerning Safety in the Use of Asbestos. In 2009 European Parliament and the Council adopted Directive $2009 / 148 /$ EC on the protection of workers from the risks related to exposure to asbestos at work ${ }^{12}$.

However, as Per Laleng supposes the number of asbestos-related deaths will reach its peak in the $2020 \mathrm{~s}^{13}$.

The aim of this article is to track the development of case law and statutory law of the United Kingdom regarding the compensation of damage caused by asbestos-related mesothelioma.

Materials of the study encompass judgements of the House of Lords and Supreme Court of the United Kingdom as well as the UK statutory law concerning compensation of damage caused by asbestos-related mesothelioma. The methodology of the paper is based on a chronological

\footnotetext{
${ }^{5}$ P. D. CARRINGTON, op. cit., p. 588.

${ }^{6}$ A. F. Lazarev, O. G. Grigoruk, L. M. Bazulina, et al. "Pleural mesothelioma: etiology, incidence, diagnostic, treatment, survival", Russian Oncologic Journal, no 5, 2013, p. 16.

7 A. F. Lazarev, O. G. Grigoruk, L. M. Bazulina, op. cit.

8 Fairchild v Glenhaven Funeral Services Ltd [2002] UKHL 22, §7.

9 P. Bogovski, V. Timbrell, J. C. Gilson, et. al. (Eds.) Biological Effects of Asbestos, IARC, Lyon, 1973.

${ }^{10}$ B. W. STEWART, \& C. P. WiLD, (Eds.), World Cancer Report, IARC, Lyon, 2014, p. 138.

11 B. W. STEWART, \& C. P. WiLD, (Eds.), op. cit.

12 OJ L 330, 16.12.2009, p. 28.

13 P. LALENG, "Is Fairchild a Leading Case of the Common Law?", The Honourable Society of Inner Temple Lecture Series, 2014, available at: https://d17g388r7gand8.cloudfront.net/2017/08/lecture laleng 2014.pdf, p. 5.
} 
survey showing the gradual evolution of the UK case law approach to causation in asbestos-related mesothelioma cases.

\section{PROOF OF CAUSATION IN TORT LAW: GENERAL RULES}

Compensation of damage caused by different wrongdoings is the objective of tort law. Briefly, the main idea of tort law can be expressed as follows: a person who has been harmed by unlawful actions of another person (tortfeasor) is entitled to claim compensation at the expense of the latter. Having combined two antecedents (first that the damage unlawfully caused has to be compensated by the culprit; second that according to medical science asbestos causes mesothelioma) one can infer the following conclusion: a person who has been exposed to deleterious effect of asbestos dust due to the wrongful actions of another person is entitled to claim compensation from the latter if the former contracts asbestosrelated disease, e.g. mesothelioma. However, in practice the case is not so straightforward as it may seem at first glance.

In tort case the court finds for the plaintiff only if all the elements of tort are present. In common law those elements are: duty; breach of duty; damage; and causation ${ }^{14}$.

It means that the court rules for the plaintiff if it is established that: in circumstances of a particular case the defendant was obliged to take into account plaintiff's interests and take reasonable precautions in order to prevent harming those interests; the defendant did not fulfill this duty; the plaintiff sustained damage; and there is a causal connection between the breach of duty by the defendant and the damage sustained by the plaintiff.

But what does it mean from the legal point of view to prove that the disease is caused by one, and not another, reason? The issue deserves special attention, since as it is aptly noted in the literature the legal concept of causality differs from the concept of causality in natural sciences $^{15}$. In addition, the legal epistemology, manifesting itself in learning the reality through the prism of procedure, also has its peculiarities and limits that make it significantly differ from scientific epistemology ${ }^{16}$.

In procedural law, there are two separate concepts: burden of proof and standard of proof. The burden of proof determines who (the plaintiff or the

${ }^{14}$ Fairchild v Glenhaven Funeral Services Ltd [2002] UKHL 22, §8; Barker v Corus UK Ltd [2006] UKHL 20, §51.

15 R. Pound, "Causation", The Yale Law Journal, vol. 67, no. 1, 1957, pp. 1 to 18; J. STAPLETon, "Choosing What We Mean by 'Causation' in the Law", Missouri Law Review, vol. 73, no. 2, 2008, pp. 433 to 480. K. SUlYOK, Managing Uncertain Causation in Toxic Exposure Cases: Lessons for the European Court of Human Rights from U.S. Toxic Tort Litigation, Vermont Journal of Environmental Law, vol. 18, 2017, pp. 525-527.

16 However, insightful observation of the correlation between science and legal approach to causation can be found in; J. CASSELS, C. JONES, "Rethinking ends and means in mass tort: Probabilistic causation and risk-based mass tort claims after Fairchild v. Glenhaven Funeral Services", Canadian Bar Review, vol. 82, no. 3, 2003, pp. 606-610. 
defendant) has to prove a particular fact. The general rule concerning the burden of proof is read as semper necessitas probandi incumbit ei qui agit, which means "it is the one who alleges that has to prove". In other words, the party who bases its claim or objection on a particular fact has to prove this fact. In a tort case causal connection is a fact on which the claim is based, and therefore, it is the plaintiff who is to prove the existence of a causal connection. If the plaintiff fails to do so he or she loses the case ${ }^{17}$.

Standard of proof defines "to what extent" the fact has to be proven in order for the court to consider it reliable enough to base a judgement on it. I.e. standard of proof sets the quality of proof that should satisfy the court. But what criterion should be used to assess the quality of proof? Since proof in the trial is aimed at persuading the court or jurors (factfinder), the degree of conviction of the fact-finder should serve as a criterion for the quality of proof. Then how to measure this degree? In common law, the concept of 'balance of probabilities' is used for the purposes of civil justice: in order to succeed in proving, it is sufficient for the party to convince the court that the probability that its assertion is true is higher than the probability of the opposite ${ }^{18}$. Put into numbers it is read as follows: a fact is considered to be proven if the party bearing the burden of proof has convinced the fact-finder that probability of this fact exceeds $50 \%{ }^{19}$. However, it should be noted that many scholars warn against such an arithmetization ${ }^{20}$.

Thus, claiming compensation for damage caused by a disease, the plaintiff has to prove that the disease was caused more likely by the actions (or omissions) of the defendant, than by any other factors.

While dealing with the issue of causality the court uses so called 'but for' test. The essence of this test is rather simple: one has to answer whether the damage would have occurred but for the actions of the defendant. If the answer is no, then the defendant's actions are the legal cause of the damage, and vice versa ${ }^{21}$. The test is grounded on an obvious idea that a fact in the absence of which the result would have occurred cannot be

17 S. STEEL, "Causation in English Tort Law: Still Wrong after all These Years", Queensland Law Journal, vol. 31, 2012, pp. 243 to 244.

18 M. BRINKMANN, "The Synthesis of Common and Civil Law Standard of Proof Formulae in the ALI/UNIDROIT Principles of Transnational Civil Procedure", Uniform Law Review, vol. 9, issue 4, 2004, p. 877; M. MARTIN-CASALS, "Causation Conundrums: Introduction to the Annotations to Sienkiewicz v. Greif (UK)", European Review of Private Law, vol. 21, issue 1, 2013, p. 302; E. VoYIAKIS, "Causation and Opportunity in Tort", Oxford Journal of Legal Studies, vol. 38, issue 1, 2018, p. 26; G. WAGNER, "Asbestos-Related Diseases in German Law", European Review of Private Law, vol. 21, issue 1, 2013, p. 324; C. R. Williams, "Burdens and Standards in Civil Litigation", Sydney Law Review, vol. 25, no 2, 2003, p. 180.

${ }^{19}$ M. MARTin-CASAls, op. cit., p. 302; C. R. Williams, op. cit., 180.

20 S. Gold, "Causation in Toxic Torts: Burdens of Proof, Standards of Persuasion, and Statistical Evidence", The Yale Law Journal, vol. 96, no 2, 1986, pp. 376 to 402; K. SULYOK, op. cit., p. 528; S. STEEL, Proof of Causation in Tort Law. Cambridge: Cambridge University Press, 2015. p. 92.

${ }^{21}$ See: H.L.A. HaRT \& T. HONORE, Causation in the Law. 2d ed. Oxford University Press, 1985, p. 110. 
deemed as the cause of the result. Despite its apparent simplicity, 'but for' test requires the court to hypothetically exclude one fact from the complex network of causal relationships and speculate what would have happened under these - changed - circumstances.

In some cases, this logical operation does not cause any difficulty, for example, in traffic accident case it is quite obvious that the victim would not have suffered injuries, but for the accident ${ }^{22}$. Instead, in other cases, determining the hypothetical alternative course of events is very difficult or even impossible task, in despite of all the achievements of the modern science.

\section{WHAT IS SO SPECIAL ABOUT THE ASBESTOS-RELATED MESOTHELIOMA CASES?}

One of the pathbreaking British cases where the court faced the problem of finding a causal link between asbestos dust and mesothelioma was Fairchild $v$ Glenhaven Funeral Services $L t d^{23}$. During his life Mr. Fairchild worked for two employers that exposed him to asbestos dust. While working on the first employer he dealt with industrial ovens lined with asbestos; while working on the second employer he cut asbestos sheeting. The court found that both employers breached the duty of care vis-à-vis Mr. Fairchild. Thus, during his lifetime Mr. Fairchild inhaled a significant amount of asbestos dust, and as a result he contracted mesothelioma of the pleura from which he died at the age of 60 years. His widow sued both of the employers in court with a view to get compensation for the disease and the death of her husband.

The crux of the case was attributable to the peculiarities of mesothelioma's pathogenesis. As put by Jane Stapleton, it is crucial to distinguish three mechanisms of disease contraction. 'Single-hit' mechanism - when a single contact with one single unit of a noxious substance (e.g. inhalation of one respirable carcinogen fiber) or one unit of virus is sufficient to trigger the disease. Second, cumulative mechanism: each contact with a noxious substance (agent) causes real damage to body tissues, and this damage increases with increasing number of contacts. Third, 'threshold' mechanism: unless a certain dose of a noxious substance accumulates in a body, the disease does not occur and no tissue damage is caused. The disease is triggered only when the amount of accumulated substance reaches a certain dose ${ }^{24}$.

From a legal point of view, in the pathogenesis of mesothelioma, two aspects are important. First, medical science does not rule out the possibility that the mechanism of genetic change, that ultimately results in mesothelioma, can be triggered by a single asbestos fiber ${ }^{25}$. Second,

\footnotetext{
${ }^{22}$ Nevertheless, some scholars suggest that even in this 'simple' cases the 'but for' test produces some illogical outcomes. For instance, see: S. HEDLEY, "Rethinking Actual Causation in Tort Law", Harvard Law Review, vol. 130, 2017, pp. 2166-2171.

23 [2002] UKHL 22.

${ }^{24}$ J. StAPLETON, "Two Causal Fictions at the Heart of U.S. Asbestos Doctrine", Law Quarterly Review, vol. 122, 2006, p. 191.

${ }^{25}$ Fairchild v Glenhaven Funeral Services Ltd [2002] UKHL 22, §7.
} 
mesothelioma is an 'indivisible disease' (according to Lord Phillips's terminology) in the sense that the severity of the disease, whenever it has been already contracted, is not dependent upon the extent of the further contact with asbestos.

So what if - taking all that into account - one try to apply to this case regular rules on proof of causation as they were explained earlier? The result would be as follows. In order to succeed the plaintiff has to prove that (a) if the first employer had not exposed Mr. Fairchild to asbestos dust, he would not have contracted mesothelioma; and (or) (b) if the second employer had not exposed Mr. Fairchild to asbestos dust, he would not have contracted mesothelioma. Specifically the plaintiff had to convince the court that at least one of the two allegations is more likely than not (i.e. probability of at least one of the two allegations is $>50 \%$ ). However the task appeared to be impossible, because the first employer can resist the claim alleging that the fatal fiber could have been inhaled when Mr. Fairchild worked for the second employer (in which case the fibers inhaled earlier when he worked for the first employer have nothing to do with the disease). And the second employer can use the similar allegation.

Therefore, given that regular rules on proof of causation apply in this case, the plaintiff can only be compensated if it clearly indicates to whom of the two employers the fatal asbestos fiber (that triggered the process of genetic changes in her husband's mesothelium cells) belonged. However modern medical science cannot precisely identify the origin the fiber. As a result, the application of the regular rules on proof of causation makes the court reject the claim on the ground that the plaintiff has not done something that no one is capable of doing 26 .

\section{FAIRCHILD EXCEPTION: MULTIPLE TORTIOUS CAUSES COMPETING}

This result appears to be even more unjust if one recalls that on the opposite side of the scale there are two employers guilty of breaching the duty to take care of the employee's health.

Thus, the House of Lords decided to depart from the regular rules on proof of causation and established an exception for this case. It was concluded

26 For comparative observations on how similar cases are approached in Spain see: A. RUDA, "Fairchild v. Glenhaven Funeral Services Ltd and others, Fox v. Spousal (Midlands) Ltd, Matthews v. Associated Portland Cement Manufacturers (1978) Ltd and others [2002] UKHL 22. Spanish case note", European Review of Private Law, vol. 2, 2004, pp. 245 to 258. For German comparative observations see: C. HATTENHAUER, "Europaiisches Deliktsrecht in Fairchild v. Glenhaven Funeral Services - Das House of Lords zwischen englischer und römischer Tradition", European Review of Private Law, vol. 2, 2004, pp. 220 to 237. For Danish comparative observations see: A. TAMASAUKAS, "Fairchild v. Glenhaven Funeral Services Ltd and others, Fox v. Spousal (Midlands) Ltd, Matthews v. Associated Portland Cement Manufacturers (1978) Ltd and others [2002] UKHL 22. Danish case note", European Review of Private Law, vol. 2, 2004, pp. 217 to 220. For Greek comparative observations see: K. N. Christodoulou, "Multiple Potential Causality in Law". European Review of Private Law, vol. 12, 2004, pp. 238-245. 
that in this case 'but for' test does not apply. Instead, it will suffice if the plaintiff proves that the defendant's actions 'materially increased the risk' of contracting mesothelioma ${ }^{27}$. Defined in this way the burden of proof became much more easier to discharge: from this point of view there is no doubt that actions of both employers have to be considered as legal causes of damage, since (as was mentioned earlier) occupational exposure to asbestos dust in 1000 times increases the risk of mesothelioma.

On this ground the House of Lords ruled in favor of the plaintiff. Both employers were held liable in solidum, i.e. without defining the share of each defendant in total sum of compensation. This means that both defendants remain to be debtors until the amount of compensation has been paid in full. None of the defendants can object to the plaintiff's claim, referring to the fact that he has already paid his share; and if one of the defendants ceases to exist, the whole amount must be paid by the one who still operates.

At the same time the approach applied in Fairchild cannot be seen as a new general rule. It is an exception to regular rule on causation which remains to be good law. The scope of this exception is precisely described by Lord Bingham ${ }^{28}$.

It seems that for the judgement in Fairchild it was crucial that both factors 'competing' for the title of legal cause were wrongful actions. Thus, Themis's scales looked as follows. On the one end - blameless widow whose husband died because of severe disease; on the other end - two employers guilty of neglecting the health of the worker; one of them did cause the disease; another though did not actually cause the disease but could have caused it; and it is merely the play of chance that it was not him who did cause the disease. So, it is not surprising that the scales moved in favor of the plaintiff.

\section{BARKER CASE: MULTIPLE BOTH TORTIOUS AND NON-TORTIOUS CAUSES COMPETING BUT THE LIABILITY IS PROPORTIONAL}

Another milestone in the development of asbestos litigation is Barker $V$ Corus UK $L t d^{29}$. In his life Mr. Barker inhaled asbestos dust during three separate periods: first - while working for Graessers Ltd company; second - while working for John Summers Ltd; and third - while working as a self-employed plasterer. Eventually he contracted mesothelioma and died. The action was brought against the two above mentioned employers on the ground that they breached the duty to take care of the employee's health and tortiously exposed him to asbestos dust.

Unlike the Fairchild case where both competing factors were tortious, in Barker there were three competing factors: two tortious and one nontortious (when somebody damages himself it is not considered as a tort). Thus the balance on the Themis's scales has shifted: now the plaintiff

\footnotetext{
${ }^{27}$ Fairchild v Glenhaven Funeral Services Ltd [2002] UKHL 22.

${ }^{28}$ Ibid., $\S 1$.

${ }^{29}$ [2006] UKHL 20.
} 
party is not that innocent anymore (since it may be that the deceased own behavior caused his mesothelioma). At the same time the "weight" of the opposite side has changed as well: though two employers are still guilty of neglecting the employee's health, it may be that neither of them was the actual cause of the employee's mesothelioma (while in Fairchild at least one of the employers for sure caused the disease).

Therefore the House of Lords had to decide whether the Fairchild exception applies to cases where among several factors, of which it is impossible to identify which one was the real cause of the damage, one factor is non-tortious (it may be the behavior of the deceased himself, the lawful conduct of third parties or natural factors).

Second issue to be resolved was the apportionment of liability among the tortfeasors, namely whether they have to be liable in solidum or instead each of them has to be liable for some portion of the total amount of damages (in Fairchild the issue was not addressed since the defendant did not object to liability in solidum ${ }^{30}$ ).

Though on the first glance it seems that the two issues do not depend on each other, the House of Lords underlined that they are tightly intertwined ${ }^{31}$.

Law is always about weighing two opposite interests and deciding which one is to prevail. Ruling in favor of the plaintiff in Fairchild, the House of Lords openly acknowledged that this decision has a margin of error: it may result in holding some employers liable for the damage they did not actually cause. Nevertheless, it was decided that such an injustice is less than injustice that would appear if all the victims of asbestos-related mesothelioma were denied compensation ${ }^{32}$.

While weighing opposite interests, it is important to consider all the relevant circumstances. Mesothelioma has a long latency period of 30-40 years $^{33}$. Therefore, by the time the victim is diagnosed with a disease it may appear that the company that once was an employer of the victim has already ceased to exist, gone bankrupt or undergone so many changes, that it is impossible to track its successor ${ }^{34}$. So if there were three employers that exposed the victim to asbestos dust and by the time the mesothelioma is diagnosed only one employer is left, then this one employer will have to bear the full amount of damages (notwithstanding the victim worked for this employer for the shortest period of time).

In fact it means that in Fairchild two steps were taken towards the asbestos-related mesothelioma victims: first, the burden of proof was significantly eased; second, the risk of ceasing or bankruptcy of a defendant is placed on the remaining defendants (so that no matter how many defendants are left by the time of the trial the plaintiff gets compensation in full). And now Barker case placed on the agenda the third

\footnotetext{
30 P. LALENG, op. cit., pp. 7-8.

${ }^{31}$ Barker v Corus UK Ltd [2006] UKHL 20, §§67, 86, 101, 107, 124.

${ }^{32}$ Fairchild v Glenhaven Funeral Services Ltd [2002] UKHL 22, §33.

${ }^{33}$ Ibid., §7.

${ }^{34}$ P. LALENG, op. cit., p. 7.
} 
step, namely the applicability of the two mentioned privileges in cases where it is possible that the disease was caused by the deceased's own behavior. The House of Lords concluded that taking this third step in raw towards the plaintiffs would upset the fair balance of the parties' interests. Yet the House of Lords decided that this step can be taken as long as it is counterweight by the shift from liability in solidum to proportional liability of the defendants. Thus eventually it was decided that (a) Fairchild exception applies to cases where one of the competing causes is nontortious; but (b) from now on each of the defendants must compensate for damage in proportion to the degree of probability that his activity was a real cause of the damage.

Suppose the total amount of damage is 100000 USD; the probability that the disease was actually caused by employer $A$ is 0.3 ; the probability that the disease was actually caused by employer $B$ is 0.5 ; the probability that the disease was actually caused by the behavior of the deceased himself is 0.2 . In this case employer $A$ has to compensate 30000 USD and employer $B-50000$ USD. Even if by the time of the trial only the employer A is left it has to compensate no more than 30000 USD.

So the injustice of holding A liable for damage it did not actually cause is mitigated by the fact that $A$ at least do not have to compensate the damage in full ${ }^{35}$.

Of course, in this case there is injustice towards the plaintiff who is undercompensated, but partial compensation is better than total absence thereof. In this way the House of Lords seems to strike a fair balance: each of the parties gets both some privileges and some burdens.

\section{COMPENSATION ACT 2006 AND SIENKIEWICZ CASE: BACK TO LIABILITY IN SOLIDUM AND "MATERIAL INCREASE IN RISK" EXPLAINED}

In 2006 legislator intruded in the development of the law regarding compensation for damage caused by asbestos-related mesothelioma. Parliament passed Compensation Act 2006. Under Art. 3(2) of the Compensation Act 2006 "[t]he responsible person shall be liable in respect of the whole of the damage caused to the victim by the disease... jointly and severally with any other responsible person". Thus, the Parliament abandoned the rule set forth in Barker case and restored the regime of liability in solidum.

After the enactment of the Compensation Act 2006 another milestone was the case Sienkiewicz $v$ Greif $(U K) L t d^{36}$. During eighteen years Mrs. Costello worked for a company that used asbestos in production of metal barrels. Mrs. Costello worked mainly in the office, but from time to time she had to visit the manufacturing premises, the air of which was polluted with asbestos dust. Subsequently, she contracted mesothelioma and died at the age of 74 years. The daughter of the deceased, Mrs. Karen

\footnotetext{
${ }^{35}$ Barker v Corus UK Ltd [2006] UKHL 20, §117.

${ }^{36}$ [2011] UKSC 10 (9 March 2011).
} 
Sienkiewicz, sued the employer company, which was found guilty of violating the duty to take care of the employee's health.

Unlike the previous cases in Sienkiewicz there was only one defendant. However the causation was unclear, since it was found that a certain amount of asbestos dust was contained in the atmospheric air of the area where Mrs. Costello lived, which meant that her mesothelioma could have been caused either by asbestos fibers from the atmosphere (so called environmental exposure) or by asbestos fibers from the manufacturing premises of the employer (so called occupational exposure).

According to the expert evidence the risk of contracting mesothelioma due to the environmental exposure alone amounted to 24 cases per million; and if the occupational exposure is added the number increases to 28.39 cases per million (increase by $18 \%$ ).

In the view of the above the Supreme Court faced the question of whether the Fairchild exception applies to cases where there is only one employer that exposed the victim to asbestos dust.

The Supreme Court answered this question in affirmative. It was stated that the Fairchild exception was called for by the impossibility to identify precisely the source of the asbestos fibers that caused mesothelioma. This impossibility holds true in the cases with one defendant as well. Lord Dyson eloquently expressed it with the following words: "The exception was devised as a matter of policy to overcome the injustice that claimants would suffer if they were prevented by the rock of uncertainty from establishing causation in mesothelioma cases. [...] There is no reason in policy or principle why the exception should not apply to a single exposure claim just as it does to a multiple exposure claim"37.

Second issue which the Supreme Court had to deal with was the following: can the increase of the risk by $18 \%$ be regarded as "material"?

The defendant argued that the increase of risk can be regarded as material only if the risk is more than doubled. This position was grounded on the combination of the epidemiological concept of relative risk (RR) and legal standard of proof known as 'balance of probabilities'38.

Relative risk is defined as the ratio of the disease incidence in a group of people exposed to a certain factor to the disease incidence in the control group that was not exposed to the factor. Thus, if $R R=1$, then there is no correlation between the factor and the disease, if $R R=2$, it means that the factor doubles the probability of the disease.

Suppose, the incidence of the disease in control group is $15 \%$, and in the group exposed to the factor $-31.5 \%$ (thus $R R=2.1$ ). It means that of 1000 people exposed to the harmful factor 315 will contract the disease; of which 150 would have contracted the disease anyway (i.e. even if they had not been exposed) and 165 would not have contracted the disease but for the exposure. Hence, if RR $>2$ then for each individual case of the

37 Sienkiewicz v Greif (UK) Ltd [2011] UKSC 10 (9 March 2011), §212.

${ }^{38}$ Ibid., §82. 
disease in the group exposed to the factor, it is statistically more likely that the disease was caused by this factor ${ }^{39}$.

As was mentioned earlier, 'balance of probabilities' standard means that a fact is deemed proven whenever the probability that this fact has happened is higher than the probability of the opposite. From this standpoint defendant's argument was read as follows. If for the occupational exposure $R R>2$, statistically the probability of the asbestos dust from the workplace being the cause of mesothelioma exceeds $50 \%$. This being so the court has to be convinced that it is more likely than not that it was the asbestos dust from the workplace (and not the asbestos from the environment) that caused deceased's mesothelioma. Conversely, if $R R<2$ (as is the case with Mrs. Costello) court should conclude that there is no causal connection between occupational exposure and the disease.

However, the Court rejected this way of thinking. As has been already mentioned, the Court declared Fairchild exception applicable in this case. The essence of Fairchild exception is that it is sufficient for the plaintiff to prove that the defendant "materially increased the risk" of contracting mesothelioma. If one supposes that "material increase in risk" denotes more than doubling the risk, that would mean that Fairchild did not set forth any exception, because whenever the plaintiff proves doubling the risk he or she by so doing satisfies regular requirements regarding the proof of causation.

On this ground the Supreme Court inferred that any increase, unless it is so small that can be reasonably disregarded, should be treated as "material" 40 . Eventually the Court decided that increase in risk by $18 \%$ cannot be disregarded and therefore the judgement has to be granted to the plaintiff.

\section{BEYOND MESOTHELIOMA: FAIRCHILD EXCEPTION APPLIED TO MULTI-AGENT DISEASE CASES}

In cases of asbestos-induced mesothelioma, the courts, on an exceptional basis, alleviated the burden of proof borne by the plaintiff. But how far shall this exception go?

With regard to the Compensation Act 2006, two points worth noting. First, it has changed the allocation of damages in the case of multiple defendants (instead of partial liability, joint and several liability was provided for); however, it has not changed the conditions of liability they remain to be determined by case law and, in particular, by the Fairchild rule. Second, Compensation Act applies to mesothelioma only and does not apply to other diseases. Thus, if the courts decide that the

39 On the doubling the risk principle see also: S. STEEL, "Uncertainty Over Causal Uncertainty: Karen Sienkiewicz (Administratrix of the Estate of Enid Costello Deceased) v Greif (UK) Ltd", The Modern Law Review, vol. 73, No. 4 2010, pp. 654-655; K. SulYok, op. cit., pp. 563-565.

40 Sienkiewicz v Greif (UK) Ltd [2011] UKSC 10 (9 March 2011), §169. 
Fairchild rule can be applied to some disease other than mesothelioma ${ }^{41}$, the joint and several liability regime established by the Compensation Act will not apply, instead the allocation of damages between defendants will be governed by Barker case providing for partial liability 42 .

The uniqueness of mesothelioma is that it can be caused by only one etiological agent, namely by asbestos. Therefore, mesothelioma is often called a "signature disease"43. In all above-mentioned cases, there was no doubt that the victim's disease had been caused by asbestos, the only question was - by which employer's asbestos was it caused? However, the situation is fundamentally different when it comes to lung cancer, for example, which can be caused by various agents, such as smoking, radon, polycyclic aromatic hydrocarbons, crystalline silica, certain metals etc., and, among other agents - by asbestos dust ${ }^{44}$. This raises the question of whether the Fairchild rule is applicable to multi-agent disease cases.

Although the question did not arise on the facts of the Barker case, Lord Scott obiter dictum stated: "[i]f, however, the case were not one of an eventual outcome produced by a single agent but of an outcome that might have been produced by one of a number of different agents and where the guilty agent could not be identified..., I would not regard the Fairchild principle as applicable. Fairchild did not establish an overarching principle. It established a narrow exception to the causation requirements applicable to single agent cases. I would not extend the exception to cover multi-agent cases as well"45.

The conclusive answer to the question was given in Heneghan $v$ Manchester Dry Docks $L t d^{46}$. In this case, Mr. James Heneghan had been exposed to asbestos dust while working for ten different employers during his lifetime. At the age of 73 he contracted lung cancer and in one year he died. For various reasons, it was not possible to sue all the employers. So, the son of the deceased filed a lawsuit against six of them. However, unlike mesothelioma, lung cancer can also be caused by smoking, and the deceased was a smoker.

Justice Jay, with reference to Jane Stapleton's comment ${ }^{47}$ on the Australian case of Amaca Pty Ltd $v$ Ellis ${ }^{48}$, noted that in this case, the causality analysis falls into two questions. First, it is necessary to find out what caused the lung cancer (which of the two competing agents):

\footnotetext{
${ }^{41}$ And as Per Laleng noticed "there is nothing within the Fairchild-Barker preconditions to its application that confines it to mesothelioma". See: P. LALENG, op. cit., p. 12.

${ }^{42}$ S. STEEL, "Causation in English Tort Law: Still Wrong after all These Years", Queensland Law Journal, vol. 31, 2012, p. 245.

43 J. StAPLETON, "Factual Causation and Asbestos Cancers", Law Quarterly Review, vol. 126, 2010 p. 354; J. C. Mosher, "A Pound of Cause for a Penny of Proof: The Failed Economy of an Eroded Causation Standard in Toxic Tort Cases", New York University Environmental Law Journal, vol. 11, 2003, p. 551; K. SulYok, op. cit., pp. 532.

44 B. W. STEWART, \& C. P. WiLD, (Eds.), op. cit., 350.

${ }^{45}$ Barker v Corus UK Ltd [2006] UKHL 20, § 64.

${ }^{46}$ [2014] EWHC 4190 (QB).

47 J. StAPLeton, "Factual Causation and Asbestos Cancers", Law Quarterly Review, vol. 126,2010 p. 351 to 356.

48 [2010] HCA 5.
} 
smoking or asbestos dust ("what" question). Second, if the cancer is found to be caused by asbestos, it is necessary to find out whether there is a causal link between the asbestos of each individual defendant and the disease. In other words, which of the defendants caused the cancer ("who" question) 49 . The Fairchild exception shall apply to the "who" question only, meanwhile the "what" question has to be decided on the basis of general rules for proving causation, viz according to the balance of probability standard.

How to approach the "what" question using the epidemiological data - it is demonstrated by Jane Stapleton in her aforementioned comment ${ }^{50}$. Following her lead, and using the data from the Heneghan case, one can obtain the following calculations.

Had the deceased neither smoked nor worked with asbestos, the risk of contracting lung cancer would have amounted to $0.5 \%$. Had the deceased smoked but not worked with asbestos the risk would have quadruple to $2 \%{ }^{51}$. Had the deceased worked with asbestos but not smoked the risk would have increased fivefold, given the duration and intensity of contact with the asbestos dust ${ }^{52}$. Moreover, it should be borne in mind that smoking and exposure to asbestos dust together have a synergistic effect $^{53}$. It means that since the deceased both smoked and worked with asbestos, the risk of disease increased by more than 9 times. Thus, for every 10,000 people who smoke and work with asbestos to the same extent as the deceased, it is plausible that more than 450 people will develop lung cancer (say, 475). Thus, of these 475 people: 50 - would have contracted the disease regardless of smoking and asbestos; 150 have contracted the disease because of smoking; 250 - have contracted the disease because of asbestos; and another 25 have contracted the disease because of synergistic effect of asbestos and smoking. Thus, in total 275 (57.9\%) people out of 475 would not have contracted the disease but for the asbestos exposure (and the greater the synergistic effect, the higher this percentage will be). This means that on the balance of probabilities in each individual case, the cancer is more likely caused by asbestos, rather than smoking. Thus, the answer to the "what" question in the Heneghan can be obtained without any relaxation of the standard of proof (since RR > 2).

With regard to the "who" question Justice Jay concluded that lung cancer and the circumstances in which it was contracted in this case meet all the requirements necessary for the application of the Fairchild rule $\mathrm{e}^{54}$. However, the alleviated burden of proof provided by the Fairchild must be applied in conjunction with the partial liability provided for in the later case - Barker. Thus, the plaintiff shall be entitled to receive only part of

\footnotetext{
${ }^{49}$ Heneghan v Manchester Dry Docks Ltd [2014] EWHC 4190 (QB), § 43.

50 J. StAPLeton, "Factual Causation and Asbestos Cancers", Law Quarterly Review, vol. 126,2010 p. 352-353.

${ }^{51}$ Heneghan v Manchester Dry Docks Ltd [2014] EWHC 4190 (QB), § 14.

52 Ibid., § 5.

53 Ibid., § 14.

${ }^{54}$ Ibid. § 79.
} 
the compensation proportional to the total asbestos exposure for which six (out of ten) employers are responsible. It is noteworthy that this figure amounted to $35.2 \%$. The lawsuit was not filed against W. Blackwell - the employer, responsible for the largest exposure of $56 \%$.

In order to circumvent the rule of partial liability, the plaintiff sought to prove that this case was distinguishable from Fairchild, and instead more similar to Bonnington Castings Ltd $v$ Wardlaw ${ }^{55}$.

In Bonnington plaintiff worked for eight years dealing with steel castings. After the moulding process some amount of sand with silica content remained on the castings' surface. In the course of castings polishing, silica dust got into the air that workers breathed. Three types of devises were used to polish the castings: floor grinders, swing grinders, and a pneumatic hammer. With regard to floor grinders and pneumatic hammer, the employer had taken all the appropriate precautions to minimize the amount of dust getting into the air (this does not mean, however, that dust formation had been completely avoided). On the other hand, with regard to swing grinders, the employer did breach the duty of care, because the ventilation shafts did not work properly. As a result, the plaintiff developed pneumoconiosis.

The crux of the case is that even had the employer provided proper ventilation, a certain amount of dust would still have got into the air. Therefore, the question arose as to whether the causation can be deemed established between the employer's negligence and the plaintiff's disease taking into account that even if the employer were faultless, silica dust (some amount of it) would anyway get into the plaintiff's lungs.

Lord Reid noted that in order to prove causation the plaintiff must show that the breach of duty by the employer "materially contributed to his injury". In this context, it is important that "pneumoconiosis is caused by a gradual accumulation in the lungs of minute particles of silica inhaled over a period of years" 56 . That being so, among all the particles contained in the plaintiff's lungs there are some "guilty" ones and some "innocent" ones. And since the proportion of "guilty" particles is not so insignificant as to be neglected, the causal link should be considered proven and the defendant must reimburse the damage in full.

The plaintiff in Heneghan insisted on the application of Bonnington precedent to shift the liability regime to joint and several liability. That would allow him to be compensated in full instead of getting only $35.2 \%$ of damage sustained.

However, Justice Jay emphasized the different etiologies of pneumoconiosis and lung cancer. Unlike pneumoconiosis, lung cancer is not caused by the gradual accumulation of noxious substances in the lungs. It is true that the higher the dose of asbestos, the greater the likelihood of lung cancer, but it is only a statistical judgment. This does not mean that each and every asbestos fiber that gets into the lungs does

\footnotetext{
${ }^{55}$ [1956] AC 613.

56 Bonnington Castings Ltd v Wardlaw [1956] AC 613.
} 
produce some injury to the tissues. Therefore, whenever cellular malignant mutation occurs it is the harmful effect of some of the fibers contained in the lungs, but not each and every of them. In the view of the above, it cannot be concluded that each of the six employers "contributed to the injury". Each of the six could have done it, but whether he did remains inscrutable. The court therefore held that the circumstances of the case corresponded to those in Fairchild and that thus liability should be partial. The decision was upheld by the Court of Appeal ${ }^{57}$. Lord Justice Tomlinson emphasized that a distinction should be drawn between contribution to the disease itself, on the one hand and contribution to the risk of contracting the disease, on the other. From that point of view, in Heneghan the latter is the case and it accords with the preconditions for Fairchild exception.

\section{CONCLUSIONS}

Peculiarities of mesothelioma pathogenesis call for revision of conventional approach to proof of causation in tort law. When it comes to compensation of damage caused by asbestos-induced mesothelioma, the application of the 'but for' test produces the result incompatible with the intuitive sense of justice. In view of this, in the case-law of the United Kingdom, the new approach has been formulated under which it is sufficient for the plaintiff to prove that the defendant materially increased the risk of the disease (and not that he actually caused the disease). This approach obviously constitutes an exception to the general rule for proving causation. The exact range of this exceptional rule's application was established in Heneghan. And so, the Fairchild became a revolving case that eventually has led to the coherent sophisticated and superfine judicial approach to causation which considers peculiarities of the diseases' etiology, pathogenesis and severity in order to provide justice notwithstanding modern state of art limits.

\section{BIBLIOGRAPHY}

BMZ (Bundesministerium für wirtschaftliche Zusammenarbeit und Entwicklung), "Asbestos". In: Environmental Handbook: documentation on monitoring and evaluating environmental impacts. Vol. III: Compendium of Environmental Standards, Vieweg, Eschborn, 1995, available at http://wgbis.ces.iisc.ernet.in/energy/HC270799/HDL/ENV/enven/vol 313.htm.

P. Bogovski, V. Timbrell, J. C. Gilson, et. al. (Eds.), Biological Effects of Asbestos, IARC, Lyon, 1973.

M. BRINKMANN, "The Synthesis of Common and Civil Law Standard of Proof Formulae in the ALI/UNIDROIT Principles of Transnational Civil Procedure", Uniform Law Review, vol. 9, issue 4, 2004, pp. 875 to 892. https://doi.org/10.1093/ulr/9.4.875

57 [2016] EWCA Civ 86. 
P. D. CARrington, "Asbestos Lessons: The Consequences of Asbestos Litigation", The Review of Litigation, vol. 26, no 3, 2007, pp. 583 to 612.

J. CASSEls, C. JONES, "Rethinking ends and means in mass tort: Probabilistic causation and risk-based mass tort claims after Fairchild v. Glenhaven Funeral Services", Canadian Bar Review, vol. 82, no. 3, 2003, pp. 597 to 644.

K. N. Christodoulou, "Multiple Potential Causality in Law". European Review of Private Law, vol. 12, 2004, pp. 238-245.

S. GolD, "Causation in Toxic Torts: Burdens of Proof, Standards of Persuasion, and Statistical Evidence", The Yale Law Journal, vol. 96, no 2, 1986, pp. 376 to 402. https://doi.org/10.2307/796423

H.L.A. HART \& T. HONORE, Causation in the Law. 2d ed. Oxford University Press,

1985.

https://doi.org/10.1093/acprof:oso/9780198254744.001.0001

C. HATTENHAUER, "Europaïsches Deliktsrecht in Fairchild v. Glenhaven Funeral Services - Das House of Lords zwischen englischer und römischer Tradition" European Review of Private Law, vol. 2, 2004, pp. 220 to 237.

S. Hedley, "Rethinking Actual Causation in Tort Law", Harvard Law Review, vol. 130, 2017, pp. 2163 to 2182.

P. LALENG, "Is Fairchild a Leading Case of the Common Law?", The Honourable Society of Inner Temple Lecture Series, 2014, available at:

https://d17g388r7gqnd8.cloudfront.net/2017/08/lecture_laleng_201 4.pdf

A. F. Lazarev, O. G. Grigoruk, L. M. Bazulina, et al., "Pleural mesothelioma: etiology, incidence, diagnostic, treatment, survival", Russian Oncologic Journal, no 5, 2013, pp. 15 to 20. (in Russian).

M. MARTIN-CASALS, "Causation Conundrums: Introduction to the Annotations to Sienkiewicz v. Greif (UK)", European Review of Private Law, vol. 21, issue 1, 2013, pp. 301 to 312.

E. R. A. Merewether \& C. W. Price, Report on Effects of Asbestos Dust on the Lungs and Dust Suppression in the Asbestos Industry, His Majesty's Stationary Office, London, 1930.

J. C. Mosher, "A Pound of Cause for a Penny of Proof: The Failed Economy of an Eroded Causation Standard in Toxic Tort Cases", New York University Environmental Law Journal, vol. 11, 2003, pp. 531 to 625.

R. Pound, "Causation", The Yale Law Journal, vol. 67, no. 1, 1957, pp. 1 to 18. https://doi.org/10.2307/793946

A. RuDA, "Fairchild v. Glenhaven Funeral Services Ltd and others, Fox v. Spousal (Midlands) Ltd, Matthews v. Associated Portland Cement Manufacturers (1978) Ltd and others [2002] UKHL 22. Spanish case note", European Review of Private Law, vol. 2, 2004, pp. 245 to 258.

J. Stapleton, "Choosing What We Mean by 'Causation' in the Law", Missouri Law Review, vol. 73, no. 2, 2008, pp. 433 to 480. 
J. Stapleton, "Factual Causation and Asbestos Cancers", Law Quarterly Review, vol. 126, 2010 p. 351 to 356.

J. Stapleton, "Two Causal Fictions at the Heart of U.S. Asbestos Doctrine", Law Quarterly Review, vol. 122, 2006 pp. 189 to 195.

S. SteEL, "Causation in English Tort Law: Still Wrong after all These Years", Queensland Law Journal, vol. 31, 2012, pp. 243 to 264.

S. SteEL, Proof of Causation in Tort Law. Cambridge: Cambridge University Press, 2015. https://doi.org/10.1017/CB09781107273689

S. STEEL, "Uncertainty Over Causal Uncertainty: Karen Sienkiewicz (Administratrix of the Estate of Enid Costello Deceased) v Greif (UK) Ltd", The Modern Law Review, vol. 73, No. 4 2010, pp. 646 to 655. https://doi.org/10.1111/j.1468-2230.2010.00812.x

B. W. SteWART, \& C. P. WILD, (Eds.), World Cancer Report, IARC, Lyon, 2014.

K. SULYOK, Managing Uncertain Causation in Toxic Exposure Cases: Lessons for the European Court of Human Rights from U.S. Toxic Tort Litigation, Vermont Journal of Environmental Law, vol. 18, 2017, pp. 519-569. https://doi.org/10.2139/ssrn.2989876

A. TAMASAUKAS, "Fairchild v. Glenhaven Funeral Services Ltd and others, Fox v. Spousal (Midlands) Ltd, Matthews v. Associated Portland Cement Manufacturers (1978) Ltd and others [2002] UKHL 22. Danish case note", European Review of Private Law, vol. 2, 2004, pp. 217 to 220.

E. VOYIAKIS, "Causation and Opportunity in Tort", Oxford Journal of Legal Studies, vol. 38, issue 1, 2018, pp. 26 to 47. https://doi.org/10.1093/ojls/gqx018

G. WAGNER, "Asbestos-Related Diseases in German Law", European Review of Private Law, vol. 21, issue 1, 2013, pp. 319 to 330.

C. R. Williams, "Burdens and Standards in Civil Litigation", Sydney Law Review, vol. 25, no 2, 2003, pp. 165 to 188.

\section{CASES}

Amaca Pty Ltd $v$ Ellis [2010] HCA 5.

Barker $v$ Corus UK Ltd [2006] UKHL 20.

Bonnington Castings Ltd v Wardlaw [1956] AC 613.

Fairchild v Glenhaven Funeral Services Ltd [2002] UKHL 22.

Heneghan v Manchester Dry Docks Ltd [2014] EWHC 4190 (QB)

Sienkiewicz v Greif (UK) Ltd [2011] UKSC 10 (9 March 2011). 